\title{
UPAYA MENINGKATKAN AKTIVITAS DAN HASIL BELAJAR SISWA DENGAN PENERAPAN METODE PENEMUAN TERBIMBING PADA MATERI KUBUS DAN BALOK DI KELAS VIII SMP SWASTA BRIGJEND KATAMSO MEDAN
}

\author{
M. Panjaitan ${ }^{1}$, Gerham Gultom ${ }^{2}$ \\ ${ }^{1)}$ Dosen Matematika FMIPA Unimed Medan \\ ${ }^{2)}$ Mahasiswa FMIPA Unimed Medan \\ marojahanpjtn@yahoo.com \\ gerhamg@yahoo.co.id
}

\begin{abstract}
ABSTRAK
Penelitian ini bertujuan untuk mengetahui apakah dengan penerapan Metode Penemuan Terbimbing pada Materi Kubus dan Balok di Kelas VIII SMP Swasta Brigjend Katamso Medan dapat meningkatkan aktivitas dan hasil belajar siswa. Jenis penelitian ini adalah penelitian tindakan kelas. Subjek dalam penelitian ini adalah Kelas VIII SMP Swasta Brigjend Katamso Medan dengan jumlah siswa 42 siswa dan objek dalam penelitian ini adalah meningkatkan aktivitas dan hasil belajar siswa dengan penerapan Metode Penemuan Terbimbing pada Materi Kubus dan Balok di Kelas VIII SMP Swasta Brigjend Katamso Medan T.A 2014/2015. Pada awal penelitian dilakukan tes awal. Siswa yang tuntas dalam tes awal ini adalah 11 siswa $(26,19 \%)$ dan rata-rata kelas 58,12. Pada siklus I diperoleh aktivitas siswa yang masuk kategori baik dan sangat baik adalah 14 siswa (33,34\%) sedangkan untuk tes hasil belajar I, siswa yang tuntas dalam tes ini sebanyak 26 siswa $(61,90 \%)$ dan rata-rata kelas 68,17. Pada siklus II diperoleh aktivitas siswa yang masuk kategori baik dan sangat baik meningkat menjadi 30 siswa (71,43\%). Sedangkan untuk hasil belajar II. Siswa yang tuntas meningkat menjadi 37 siswa $(88,10 \%)$ dan rata-rata kelas 79,35. Karena presentase aktivitas siswa yang masuk dalam kategori baik dan sangat baik telah mencapai $\geq 70 \%$ dari banyak siswa dan telah mencapai paling sedikit daya serap klasikal $\geq 85 \%$, maka pembelajaran pada siklus II telah berhasil. Dengan demikian dapat disimpulkan bahwa metode pembelajaran penemuan terbimbing dapat meningkatkan aktivitas dan hasil belajar siswa khususnya pada materi kubus dan balok di kelas VIII SMP Swasta Brigjend Katamso Medan.
\end{abstract}

Kata Kunci:Aktivitas dan Hasil Belajar Siswa, Metode Penemuan Terbimbing, Kubus dan Balok.

\section{ABSTRACT}

The purpose of this research is to know whether by Guidance Discovery Method in Cube and Bar material for grade VIII SMP Swasta Brigjend Katamso Medan can improve the activity and students' study result. The kind of this research is classroom action research which had been held in 2 cycles. The subject of this research is grade VIII of SMP Swasta Brigjend Katamso Medan with the total is 42 students and the object of this research is improving the activity and students' study result by applying Guidance Discovery Method in Cube and Bar material for grade VIII SMP Swasta Brigjend Katamso Medan T.A 2014/2015. At the beginning of this research. The students who had passed the pre test were 11 students $(26,19 \%)$ and the class average score was 58,12\%. The cycle I, the activity of students which acquired as good and very good category were 14 students $(33,34 \%)$, whereas the test I of study results who passed the test were 26 students $(61,90 \%)$ and the class average score was 68,17. The cycle II, activity of students which acquired as good and very good category improved become 30 students

Marojahan Panjaitan, Gerham Gultom Upaya Meningkatkan Aktivitas dan Hasil Belajar Siswa dengan Penerapan Metode Penemuan Terbimbing pada Materi Kubus dan Balok di Kelas VIII SMP Swasta Brigjend Katamso Medan. Jurnal Inspiratif, Vol. 3, No. 3 Desember 2017. 
(71,43\%). Whereas the test II of study results who passed the test were 37 students $(88,10 \%)$ and the class average score was 79,35. Because of the percentage of the activity of students as good and very good category had achieved $\geq 70 \%$ of the subject and had achieved classical comprehended capacity $\geq 85 \%$, so the study in cycle II had been succeed. So, it can be concluded that Guidance Discovery Method can improve the activity and the study result of the students especially in cube and bar material for grade VIII SMP Swasta Brigjend Katamso Medan.

Keywords: Activity and Students' Study, Guidance Discovery Method, Cube and Bar.

\section{PENDAHULUAN}

Matematika merupakan salah satu bidang studi yang menduduki peranan penting dalam pendidikan, hal ini dapat dilihat dari waktu jam pelajaran sekolah lebih banyak dibandingkan pelajaran lain. Matematika adalah segala sumber dari ilmu yang lain. Dengan kata lain, banyak ilmuilmu lain yang penemuan dan perkembangannya bergantung dari matematika. Matematika adalah ilmu dasar yang berkembang pesat baik materi maupun kegunaannya dalam kehidupan sehari-hari. Matematika adalah suatu alat untuk mengembangkan kemampuan berpikir, karena itu matematika sangat diperlukan baik dalam kehidupan sehari-hari maupun dalam kemajuan ilmu pengetahuan dan teknologi (IPTEK), sehingga matematika perlu diberikan pada setiap jenjang pendidikan mulai dari SD hingga perguruan tinggi. Banyak hal yang menjadi penyebab kesulitan siswa dalam mempelajari matematika sehingga dapat kita ketahui bahwa peningkatan kualitas pendidikan di Indonesia terutama pelajaran matematika tidak terlepas dari interaksi antara siswa dan guru. Rendahnya hasil belajar matematika siswa merupakan tantangan serius bagi dunia pendidikan dan semua pihak yang berkecimbung dalam pendidikan matematika khususnya guru. Guru perlu mencari pendekatan pembelajaran membangkitkan motivasi belajar siswa, dan untuk siswa diharapkan lebih giat menggali dan memahami konsep - konsep dalam matematika. Hal ini dimaksud agar siswa tidak jenuh dalam menerima dan mengikuti proses belajar mengajar matematika.
Salah satu faktor yang mempengaruhi rendahnya hasil belajar matematika adalah adanya anggapan siswa bahwa matematika pelajaran yang sangat sulit sebagaimana yang diungkapkan Abdurrahman (2012) bahwa:'Dari berbagai bidang studi yang diajarkan disekolah, matematika merupakan bidang studi yang dianggap paling sulit oleh para siswa, baik yang berkesulitan belajar dan lebih - lebih bagi siswa yang berkesulitan belajar".

Faktor lain yang mempengaruhi hasil belajar siswa rendah adalah metode pembelajaran. Penerapan metode dan model pembelajaran yang tepat diperlukan demi berhasilnya proses pendidikan dan usaha pembelajaran di sekolah. Seperti yang diungkapkan oleh Slameto (2012) bahwa:

Metode mengajar guru yang kurang baik diakibatkan karena guru kurang persiapan dan kurang menguasai bahan pelajaran sehingga guru tersebut menyajikannya tidak jelas atau sikap guru terhadap siswa atau terhadap mata pelajaran itu sendiri tidak baik, sehingga siswa kurang senang terhadap pelajaran atau gurunya, akibatnya siswa malas untuk belajar dan mencatat materi pelajaran yang sedang dipelajari. Surya (2013) menenmukan faktor guru, antara lain : a) masih ada guru yang pendidikannya tidak sesuai dengan mata pelajaran, b) penguasaan guru terhadap materi matematika yang diajarkan masih sangat rendah. Hal ini dapat dilihat dari hasil probing tes guru yang menunjukkan masih terdapat guru yang hanya menguasai $40 \%$ dari tes probing yang dilakukan, c) Guru kurang menguasai materi pembelajaran secata menyeluruh. Hal ini berdasarkan

Marojahan Panjaitan, Gerham Gultom Upaya Meningkatkan Aktivitas dan Hasil Belajar Siswa dengan Penerapan Metode Penemuan Terbimbing pada Materi Kubus dan Balok di Kelas VIII SMP Swasta Brigjend Katamso Medan. Jurnal Inspiratif, Vol. 3, No. 3 Desember 2017. 
masukan dari angket siswa yang menyatakan bahwa siswa sulit memahami pelajaran yang diberikan guru. Guru seharusnya melibatkan siswa secara aktif dalam belajar tidak hanya ceramah. Guru sebaiknya menggunakan fasilitas dan sumber belajar yang lebih baik lagi dan guru sebaiknya memperbaiki cara mengajar, d) Model pembelajaran yang digunakan guru matematika masih belum bervariasi umumnya guru mengajar dengan metode ceramah. Kemampuan pedagogik guru juga masih minim, kegiatan pembelajaran yang dilakukan masih konvensional, siswa hanya pasif sebagai pendengar. Pembelajaran umumnya satu arah dimana guru memberikan atau menyalin materi atau rumus-rumus, memberikan contoh soal matematika dan dilanjutkan dengan tugas di kelas atau di rumah..Pembelajaran tidak sepenuhnya mengacu pada RPP yang ada, menurut guru ini terjadi karena keterbatasan alat. Hal ini juga menunjukkan bahwa guru juga masih memerlukan pelatihan pengembangan RPP berbasis KTSP/Kurikulum 2013, sehingga guru tidak hanya mencontoh RPP dari sumber lain, e) media atau sumber pembelajaran yang digunakan dalam pembelajaran matematika juga kurang maksimal. Guru-guru hanya berorientasi pada buku paket yang ada. Tes yang dilakukan dalam pembelajaran juga kurang standar. Guru kurang menerapkan authentic assessment seperti penilaian project, unjuk kerja dan lain-lain. Sehingga ujian yang dilakukan guru-guru berada di bawah standar UN dan terdapat perbedaan yang signifikan antara nilai ujian ulangan yang diberikan guru dengan nilai UN siswa.

Kesulitan yang diperoleh siswa adalah pada saat memahami, menggambar diagram, membaca grafik dengan benar, pemahaman konsep matematika formal, dan penyelesaian masalah matematika. Penyajian masalah yang tepat adalah hal mendasar dalam memahami masalah tersebut dan membuat rencana untuk menyelesaikannya (Surya, dkk., 2013).

Mengingat pentingnya proses belajar mengajar matematika maka guru dituntut untuk mampu menyesuaikan, memilih, dan memadukan metode pembelajaran yang tepat dalam pembelajaran matematika. Metode pembelajaran tersebut harus disesuaikan materi, kondisi siswa dan tujuan yang ingin dicapai. Selain itu strategi pembelajaran yang digunakan oleh guru harus mampu menciptakan susasana yang menyenangkan dalam belajar. Proses pembelajaran yang demikian nantinya akan sesuai dengan tujuan yang diharapkan yaitu peningkatan aktivitas. Belajar bukanlah sekedar menghafal konsep-konsep yang sudah ada atau informasi yang sudah diketahui sebelumnya melainkan belajar adalah berbuat, memperoleh pengalaman tertentu sesuai dengan tujuan yang diharapkan. Oleh karena itu metode pembelajaran harus dapat mendorong aktivitas belajar siswa. Adapun pengertian aktivitas belajar siswa menurut Kunandar (2008), yaitu:

Aktivitas belajar siswa adalah keterlibatan siswa dalam bentuk sikap, pikiran, perhatian, dan aktivitas dalam kegiatan pembelajaran guna menunjang keberhasilan proses belajar mengajar dan memperoleh manfaat dari kegiatan tersebut. Peningkatan aktivitas siswa yaitu meningkatnya jumlah siswa yang terlibat aktif belajar, meningkatnya jumlah siswa yang bertanya dan menjawab, meningkatnya jumlah siswa yang saling berinteraksi membahas materi pembelajaran. Indikator aktivitas siswa dapat dilihat dari: pertama, mayoritas siswa beraktivitas dalam pembelajaran; kedua, aktivitas pembelajaran didominasi oleh siswa; ketiga, mayoritas siswa mampu mengerjakan tugas yang diberikan guru.

Berdasarkan hasil wawancara yang dilakukan oleh peneliti di SMP Swasta Brigjend Katamso Medan kepada bapak

Marojahan Panjaitan, Gerham Gultom Upaya Meningkatkan Aktivitas dan Hasil Belajar Siswa dengan Penerapan Metode Penemuan Terbimbing pada Materi Kubus dan Balok di Kelas VIII SMP Swasta Brigjend Katamso Medan. Jurnal Inspiratif, Vol. 3, No. 3 Desember 2017. 
Radiun Situmeang,S.Pd selaku guru bidang studi matematika kelas VIII menyatakan bahwa: Aktivitas belajar siswa masih rendah. Seperti kurang aktifnya siswa dalam bertanya dalam materi yang kurang dipahami, kurangnya siswa dalam memahami masalah atau mendengarkan penjelasan dari guru, kurangnya kemampuan siswa dalam menjawab soal yang diberikan guru, dan kurangnya kemauan siswa dalam melaksanakan /mengerjakan tugas yang diberikan guru. Dan minat belajar siswa di kelas VIII pada pelajaran matematika juga masih kurang. Hal ini dapat dilihat dari rendahnya hasil belajar yang diperoleh siswa kelas VIII karena masih banyak siswa yang memperoleh nilai di bawah rata - rata kelas. Berdasarkan permasalahan di atas dapat dikatakan bahwa dalam proses pembelajaran diperlukan suatu metode, strategi, ataupun model pembelajaran yang dapat melatih kemampuan dalam meningkatkan hasil belajar siswa, melibatkan aktivitas siswa secara optimal, dan membuat pembelajaran matematika menjadi lebih bermakna dan menyenangkan. Guru dituntut dapat memilih metode pembelajaran yang dapat memacu semangat setiap siswa untuk secara aktif ikut terlibat dalam pengalaman belajarnya.

Pembelajaran yang baik diharapkan sebanyak mungkin melibatkan peran aktif siswa agar mampu berekspresi untuk membentuk kompetensi dengan menggali berbagai potensi dan kebenaran secara ilmiah sehingga menimbulkan motivasi belajar. Salah satu metode pembelajaran yang melibatkan peserta didik secara aktif adalah metode pembelajaran penemuan terbimbing karena dengan metode ini siswa dibimbing untuk mengembangkan pola pikir kreatif, inovatif dalam belajar matematika. Metode penemuan terbimbing ini merupakan salah satu metode belajar yang lebih menuntut siswa agar lebih aktif dalam menemukan dan memecahkan masalah sendiri, sedangkan guru hanya berperan sebagai pembimbing atau yang memberikan petunjuk dalam menyelesaikan masalah. Dengan proses penemuan terbimbing, siswa tidak hanya menghafal tetapi memahami, mengingat dan mengaplikasikan materi yang telah dipelajarinya. Hal ini sejalan dengan pernyataan Bruner (dalam Hamid 2009:24) yang mengemukakan bahwa:

Pengetahuan yang diperoleh dengan belajar penemuan menunjukkan beberapa kebaikan, (1) Pengetahuan itu bertahan lama atau lama diingat, (2) Hasil belajar penemuan mempunyai efek transfer yang lebih baik dari pada hasil belajar lainnya, (3) Secara menyeluruh belajar penemuan meningkatkan penalaran siswa dan kemampuan untuk berpikir secara bebas.

\section{HIPOTESIS PENELITIAN}

Berdasarkan latar belakang, rumusan masalah, dan kerangka teoritis, maka yang menjadi hipotesis dalam penelitian ini adalah terjadinya peningkatan aktivitas dan hasil belajar siswa dengan menerapkan metode penemuan terbimbing pada materi kubus dan balok di kelas VIII SMP Swasta Brigjend Katamso..

\section{METODE PENELITIAN}

Penelitian ini adalah penelitian tindakan kelas yang dilakukan di SMP Swasta Brigjend Katamso Medan. Dengan subjek penelitan adalah kelas VIII-3 yang berjumlah 42 siswa, dimana objek penelitian ini adalah upaya meningkatkan aktivitas dan hasil belajar siswa dengan penerapan metode penemuan terbimbing pada materi kubus dan balok di kelas VIII SMP Swasta Brigjend Katamso Medan.

Penelitian ini memiliki beberapa tahap yang merupakan suatu siklus. Tiap siklus dilaksanakan sesuai dengan perubahan yang akan dicapai. Secara lebih rinci, prosedur pelaksanaan penelitian tindakan kelas berdasarkan alurnya menurut Arikunto (2010:137) dapat digambarkan sebagai berikut: 


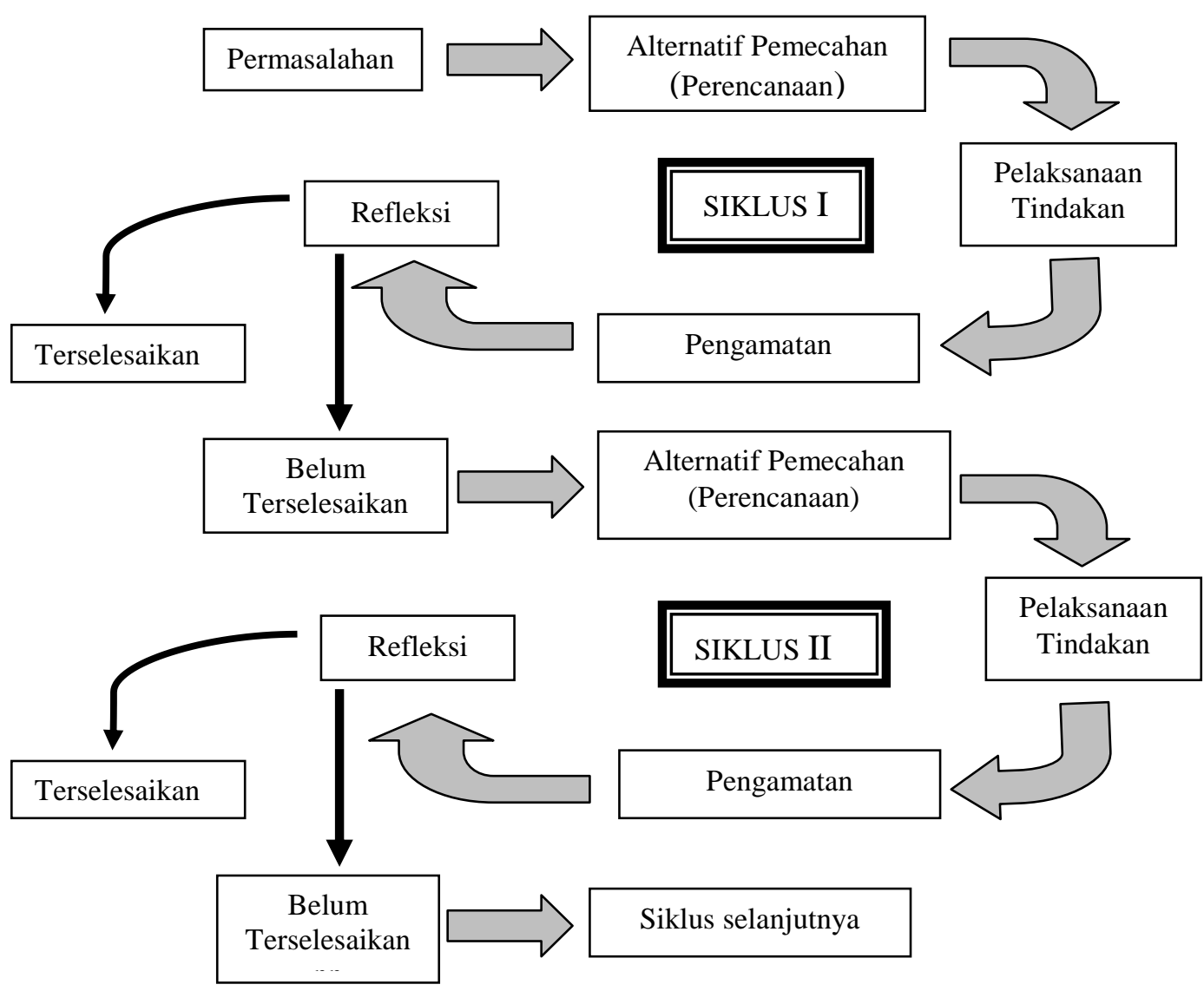

Gambar 1. Prosedur Penelitian Tindakan Kelas

Alat yang digunakan untuk mengumpulkan data pada penelitian ini adalah tes, observasi, wawancara. Setelah data-data diperoleh kemudian data-data tersebut dianalisa. Analisa dilakukan melalui tiga tahap, yaitu reduksi data, paparan data dan penarikan kesimpulan.

Dalam penelitian ini indikator keberhasilan siswa adalah sebagai berikut:

1. Aktivitas belajar siswa dikatakan berhasil jika:

$>$ Aktivitas belajar siswa dalam proses belajar mengajar sekurang kurangnya $70 \%$ berperan aktif dalam pembelajaran.

$>$ Tercapainya keaktifan belajar matematika siswa dengan jumlah siswa yang masuk dalam kategori baik dan sangat baik yakni sebesar $\geq 70 \%$ dari banyak siswa.

2. Hasil belajar matematika siswa dikatakan berhasil jika:
Hasil belajar siswa telah mencapai nilai $\geq 70 \%$.

$>$ Dalam kelas tersebut terdapat $85 \%$ siswa yang telah mencapai nilai $\geq$ $70 \%$.

Apabila indikator keberhasilan di atas tercapai maka pembelajaran yang dilaksanakan peneliti dapat dikatakan berhasil. Tetapi jika indikatornya belum tercapai maka pengajaran yang dilaksanakan belum berhasil dan dilanjutkan ke siklus berikutnya dengan mempertimbangkan hasil observasi terhadap peneliti sebagai guru selama proses pembelajaran, untuk diperbaiki pada siklus berikutnya.

\section{HASIL DAN PEMBAHASAN \\ Hasil Penelitian \\ Siklus I}

Berdasarkan hasil observasi dan tes selama pelaksanaan kegiatan yang telah dilakukan pada siklus I, diperoleh bahwa pembelajaran dengan metode penemuan

Marojahan Panjaitan, Gerham Gultom Upaya Meningkatkan Aktivitas dan Hasil Belajar Siswa dengan Penerapan Metode Penemuan Terbimbing pada Materi Kubus dan Balok di Kelas VIII SMP Swasta Brigjend Katamso Medan. Jurnal Inspiratif, Vol. 3, No. 3 Desember 2017. 
terbimbing pada siklus ini tergolong kategori baik $(3,125)$ namun masih perlu ditingkatkan. Sedangkan aktivitas siswa yang masuk dalam kategori baik dan sangat baik mengalami peningkatan dari 14 siswa $(33,33 \%)$ pada pertemuan I menjadi 18 siswa $(42,86 \%)$ pada pertemuan II namun jika dirata - ratakan aktivitas siswa yang masuk dalam kategori baik dan sangat baik pada siklus I adalah 14 siswa $(33,34 \%)$ masih tergolong cukup aktif.

Tabel 1. Rekapitulasi Hasil Observasi Aktivitas Siswa Siklus I

\begin{tabular}{|c|c|c|c|c|c|}
\hline \multirow{2}{*}{ PAS } & \multirow{2}{*}{ Kriteria } & \multicolumn{2}{|c|}{ Pertemuan I } & \multicolumn{2}{c|}{ Pertemuan II } \\
\cline { 3 - 6 } & & Jlh Siswa & \% & Jlh Siswa & \% \\
\hline PAS $\geq 85 \%$ & Sangat Aktif & 0 & $0 \%$ & 0 & $0 \%$ \\
\hline $70 \% \leq P A S<85 \%$ & Aktif & 14 & $33,33 \%$ & 18 & $42,86 \%$ \\
\hline $60 \% \leq P A S<70 \%$ & Cukup Aktif & 10 & $23,81 \%$ & 10 & $23,81 \%$ \\
\hline PAS $<60 \%$ & Kurang Aktif & 18 & $42,86 \%$ & 14 & $33,33 \%$ \\
\hline
\end{tabular}

Rendahnya aktivitas siswa tentunya berpengaruh pada hasil belajar siswanya tersebut terbukti bahwa setelah diberikan tes hasil belajar I diperoleh jumlah siswa yang tuntas adalah 26 siswa $(61,90 \%)$ dari 42 siswa dengan rata - rata kelas yang diperoleh 68,17 .

Tabel 2. Tingkat Penguasaan Siswa Pada Tes Hasil Belajar I

\begin{tabular}{|c|c|c|c|}
\hline $\begin{array}{c}\text { Tingkat } \\
\text { Penguasaan }\end{array}$ & Kategori & $\begin{array}{c}\text { Banyak } \\
\text { siswa }\end{array}$ & $\begin{array}{c}\text { Persentase } \\
\text { Banyak Siswa }\end{array}$ \\
\hline $90 \% \leq T P \leq 100 \%$ & Sangat Tinggi & 0 & $0 \%$ \\
\hline $80 \% \leq T P<90 \%$ & Tinggi & 4 Siswa & $9,52 \%$ \\
\hline $70 \% \leq T P<80 \%$ & Sedang & 22 Siswa & $52,38 \%$ \\
\hline $60 \% \leq T P<70 \%$ & Rendah & 11 Siswa & $26,19 \%$ \\
\hline $0 \% \leq T P<60 \%$ & Sangat Rendah & 5 Siswa & $11,91 \%$ \\
\hline \multicolumn{2}{|r|}{ Rata-rata Kelas } & $\mathbf{6 8 , 1 7}$ & \\
\hline
\end{tabular}

Walaupun mengalami peningkatan dari tes awal yaitu hanya 11 siswa $(26,19 \%)$ yang tuntas dan rata - rata kelas 58,12, Hal ini tentunya belum memenuhi kriteria ketuntasan klasikal dan juga kriteria ketuntasan minimal. Maka secara keseluruhan dapat disimpulkan bahwa pelaksanaan tindakan siklus I ini telah mengalami peningkatan tetapi belum mengalami keberhasilan.

Siklus II

Berdasarkan hasil observasi dan tes selama pelaksanaan kegiatan yang telah dilakukan pada siklus II, diperoleh bahwa pembelajaran dengan metode penemuan terbimbing pada siklus ini tergolong kategori baik $(3,375)$ dan mengalami peningkatan dari pelaksanaan siklus I. Hal ini tentunya dilihat dari meningkatnya aktivitas siswa pada proses pembelajaran. Aktivitas siswa yang masuk dalam kategori baik dan sangat baik mengalami peningkatan dari 14 siswa $(33,34 \%)$ pada siklus I menjadi 30 siswa $(71,43 \%)$ pada siklus II.

Tabel 3. Rekapitulasi Hasil Observasi Aktivitas Siswa Siklus II

\begin{tabular}{|c|c|c|c|c|c|}
\hline \multirow{2}{*}{ PAS } & \multirow{2}{*}{ Kriteria } & \multicolumn{2}{|c|}{ Pertemuan I } & \multicolumn{2}{c|}{ Pertemuan II } \\
\cline { 3 - 6 } & & Jlh Siswa & \% & Jlh Siswa & \% \\
\hline PAS $\geq 85 \%$ & Sangat Aktif & 2 & $4,76 \%$ & 12 & $28,57 \%$ \\
\hline $70 \% \leq P A S<85 \%$ & Aktif & 21 & $50,00 \%$ & 23 & $54,76 \%$ \\
\hline $60 \% \leq$ PAS $<70 \%$ & Cukup Aktif & 12 & $28,57 \%$ & 7 & $16,67 \%$ \\
\hline PAS $<60 \%$ & Kurang Aktif & 7 & $16,67 \%$ & 0 & $0 \%$ \\
\hline
\end{tabular}

Marojahan Panjaitan, Gerham Gultom Upaya Meningkatkan Aktivitas dan Hasil Belajar Siswa dengan Penerapan Metode Penemuan Terbimbing pada Materi Kubus dan Balok di Kelas VIII SMP Swasta Brigjend Katamso Medan. Jurnal Inspiratif, Vol. 3, No. 3 Desember 2017. 
Peningkatan aktivitas siswa tersebut tentunya berpengaruh pada hasil belajar siswanya, terbukti bahwa setelah diberikan tes hasil belajar II diperoleh jumlah siswa yang tuntas adalah 37 siswa
$(88,10 \%)$ dari 42 siswa dengan rata - rata kelas yang diperoleh 79,35, mengalami peningkatan dari tes hasil belajar I yaitu hanya 26 siswa $(61,90 \%)$ yang tuntas dan rata - rata kelas 68,17.

Tabel 4. Tingkat Penguasaan Siswa Pada Tes Hasil Belajar II

\begin{tabular}{|c|c|c|c|}
\hline Tingkat Penguasaan & Kategori & $\begin{array}{c}\text { Banyak } \\
\text { siswa }\end{array}$ & $\begin{array}{c}\text { Persentase } \\
\text { Banyak Siswa }\end{array}$ \\
\hline $90 \% \leq T P \leq 100 \%$ & Sangat Tinggi & 9 Siswa & $21,43 \%$ \\
\hline $80 \% \leq T P<90 \%$ & Tinggi & 16 Siswa & $38,10 \%$ \\
\hline $70 \% \leq T P<80 \%$ & Sedang & 12 Siswa & $28,57 \%$ \\
\hline $60 \% \leq T P<70 \%$ & Rendah & 3 Siswa & $7,14 \%$ \\
\hline $0 \% \leq T P<60 \%$ & Sangat Rendah & 2 Siswa & $4,76 \%$ \\
\hline \multicolumn{2}{|r|}{ Rata-rata Kelas } & $\mathbf{7 9 , 3 5}$ & \\
\hline
\end{tabular}

Hal ini tentunya telah memenuhi kriteria ketuntasan klasikal dan juga kriteria ketuntasan minimal. Maka secara keseluruhan dapat disimpulkan bahwa pelaksanaan tindakan siklus II ini telah berhasil.

\section{Pembahasan Hasil Penelitian}

Penerapan metode penemuan terbimbing dapat meningkatkan aktivitas dan hasil belajar siswa. Berdasarkan hasil penelitian, sebelum diberi tindakan kelas sampai dengan pemberian tindakan siklus II, tingkat penguasaan siswa mengalami peningkatan. Keterangan selengkapnya dapat dilihat melalui tabel berikut:

Tabel 5. Peningkatan Penguasaan Siswa

\begin{tabular}{|l|l|l|l|l|l|l|l|}
\hline \multirow{2}{*}{$\begin{array}{l}\text { Tingkat } \\
\text { Penguasaan }\end{array}$} & \multirow{2}{*}{ Kategori } & \multicolumn{2}{l|}{ Tes Awal } & \multicolumn{2}{l|}{ THB I } & \multicolumn{2}{l|}{ THB II } \\
\cline { 3 - 8 } & & Jlh & $\%$ & Jlh & $\%$ & Jlh & $\%$ \\
\hline $90 \% \leq T P \leq 100 \%$ & Sangat Tinggi & 0 & $0 \%$ & 0 & $0 \%$ & 9 & $21,43 \%$ \\
\hline $80 \% \leq T P<90 \%$ & Tinggi & 0 & $0 \%$ & 4 & $9,52 \%$ & 16 & $38,10 \%$ \\
\hline $70 \% \leq T P<80 \%$ & Sedang & 11 & $26,19 \%$ & 22 & $52,38 \%$ & 12 & $28,57 \%$ \\
\hline $60 \% \leq T P<70 \%$ & Rendah & 11 & $26,19 \%$ & 11 & $26,19 \%$ & 3 & $7,14 \%$ \\
\hline $0 \% \leq T P<60 \%$ & Sangat Rendah & 20 & $47,62 \%$ & 5 & $11,91 \%$ & 2 & $4,76 \%$ \\
\hline
\end{tabular}

Berdasarkan tabel di atas dapat dilihat tingkat ketuntasan siswa juga mengalami peningkatan. Pada tes awal jumlah siswa yang tuntas adalah 11 siswa $(26,19 \%)$ didukung dengan rata - rata kelas 58,12. Pada siklus I jumlah siswa yang tuntas bertambah menjadi 26 siswa $(61,90 \%)$ didukung dengan rata - rata 68,17 . Pada siklus II jumlah siswa yang tuntas menjadi 37 siswa $(88,10 \%)$ dengan rata - rata 79,35. Keterangan selengkapnya dapat dilihat melalui tabel berikut:

Marojahan Panjaitan, Gerham Gultom Upaya Meningkatkan Aktivitas dan Hasil Belajar Siswa dengan Penerapan Metode Penemuan Terbimbing pada Materi Kubus dan Balok di Kelas VIII SMP Swasta Brigjend Katamso Medan. Jurnal Inspiratif, Vol. 3, No. 3 Desember 2017. 
Tabel 6. Peningkatan Ketuntasan Klasikal Belajar Siswa

\begin{tabular}{|l|l|l|l|l|l|l|l|}
\hline \multirow{2}{*}{$\begin{array}{l}\text { Tingkat } \\
\text { Ketuntasan }\end{array}$} & \multirow{2}{*}{ Kriteria } & \multicolumn{2}{l|}{ Tes Awal } & \multicolumn{2}{l|}{ THB I } & \multicolumn{2}{l|}{ THB II } \\
\cline { 3 - 9 } & & Jlh & \% & Jlh & \% & Jlh & \% \\
\hline $0 \% \leq K B<70 \%$ & Tidak tuntas & 31 & $73,81 \%$ & 16 & $38,10 \%$ & 5 & $11,90 \%$ \\
\hline $70 \% \leq K B \leq 100 \%$ & Tuntas & 11 & $26,19 \%$ & 26 & $61,90 \%$ & 37 & $88,10 \%$ \\
\hline Rata - rata Kelas & \multicolumn{3}{|l|l|l|l|}{58,12} & 68,17 & 79,35 \\
\hline
\end{tabular}

Peningkatan aktivitas siswa tersebut tentunya berpengaruh pada hasil belajar siswanya, terbukti

bahwa setelah diberikan tes hasil belajar II diperoleh jumlah siswa yang tuntas adalah 37 siswa $(88,10 \%)$ dari 42 siswa dengan rata - rata kelas yang diperoleh 79,35, mengalami peningkatan dari tes hasil belajar I yaitu hanya 26 siswa $(61,90 \%)$ yang tuntas dan rata - rata kelas
68,17. Hal ini tentunya telah memenuhi kriteria ketuntasan klasikal dan juga kriteria ketuntasan minimal. Maka secara keseluruhan dapat disimpulkan bahwa pelaksanaan tindakan siklus II ini telah berhasil.

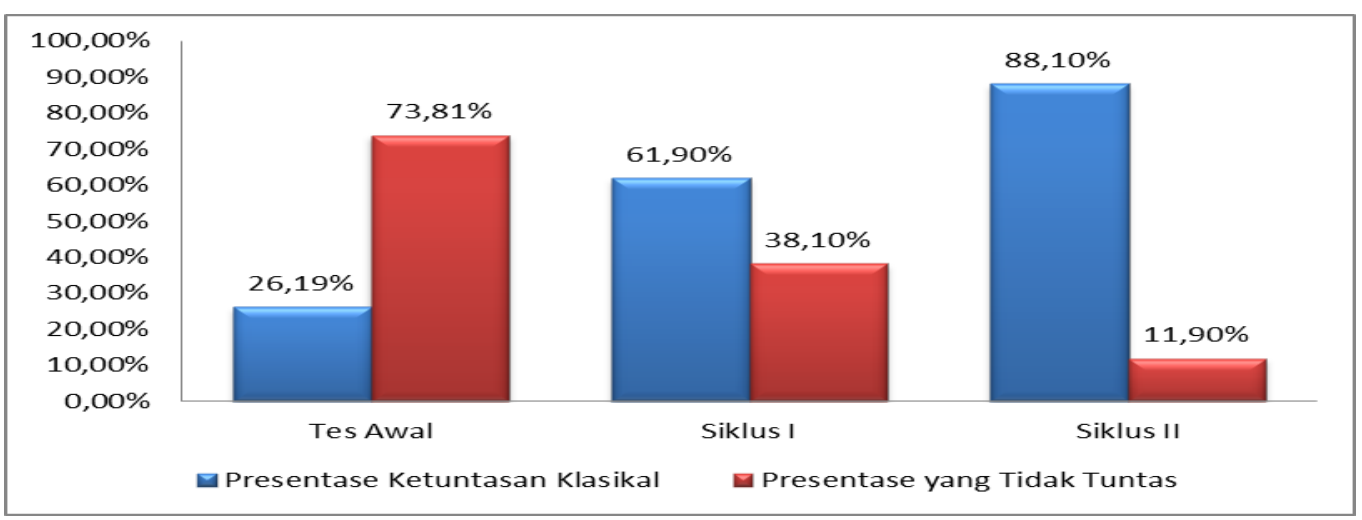

Gambar 2. Peningkatan Ketuntasan Klasikal Belajar Siswa

Selain ketuntasan hasil belajar siswa yang meningkat, terdapat pula peningkatan aktivitas belajar siswa yang ditinjau dari pertambahan persentase siswa yang sekurang - kurangnya berada pada kategori aktif yaitu 38,09\%. Keterangan selengkapnya dapat dilihat melalui tabel berikut:

Tabel 7. Persentase Peningkatan Aktivitas Belajar Siswa

\begin{tabular}{|c|c|c|c|c|c|}
\hline \multirow{2}{*}{ Tingkat Aktivitas } & \multirow{2}{*}{ Kriteria } & \multicolumn{2}{|c|}{ SIKLUS I } & \multicolumn{2}{|c|}{ SIKLUS II } \\
\hline & & Jumlah & $\%$ & Jumlah & $\%$ \\
\hline $\mathrm{PAS} \geq 85 \%$ & Sangat Aktif & 0 & $0 \%$ & 5 Siswa & $11,91 \%$ \\
\hline $70 \% \leq$ PAS $<85 \%$ & Aktif & 14 Siswa & $33,34 \%$ & 25 Siswa & $59,52 \%$ \\
\hline $60 \% \leq$ PAS < $70 \%$ & Cukup Aktif & 10 Siswa & $23,80 \%$ & 12 Siswa & $28,57 \%$ \\
\hline PAS $<60 \%$ & Kurang Aktif & 18 Siswa & $42,86 \%$ & 0 & $0 \%$ \\
\hline $\mathrm{PAS} \geq 70 \%$ & $\begin{array}{l}\text { Aktif/Sangat } \\
\text { Aktif }\end{array}$ & 14 Siswa & $33,34 \%$ & 30 Siswa & $71,43 \%$ \\
\hline
\end{tabular}

Marojahan Panjaitan, Gerham Gultom Upaya Meningkatkan Aktivitas dan Hasil Belajar Siswa dengan Penerapan Metode Penemuan Terbimbing pada Materi Kubus dan Balok di Kelas VIII SMP Swasta Brigjend Katamso Medan. Jurnal Inspiratif, Vol. 3, No. 3 Desember 2017. 
Aktivitas siswa yang masuk dalam kategori baik dan sangat baik mengalami peningkatan dari 14 siswa $(33,34 \%)$ pada siklus I menjadi 30 siswa $(71,43 \%)$ pada siklus II. peningkatan aktivitas siswa tersebut tentunya berpengaruh pada hasil belajar siswanya.

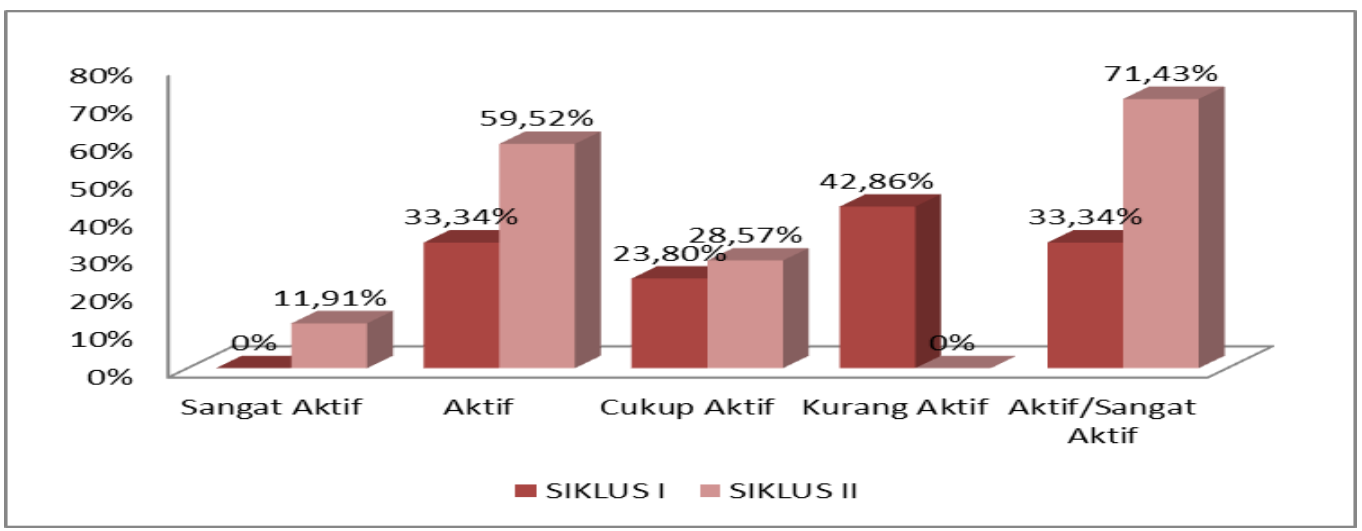

Gambar 3. Persentase Peningkatan Aktivitas Belajar Siswa

Dari hasil observasi pada siklus I dan siklus II telah tampak terjadinya peningkatan aktivitas. Pada siklus I terdapat 14 siswa $(33,34 \%)$ yang mencapai kategori baik dan sangat baik sedangkan pada siklus II terdapat 30 siswa $(71,43 \%)$ yang mencapai kategori baik dan sangat baik. Maka dapat disimpulkan bahwa, presentase ini sudah mencapai kriteria peningkatan aktivitas belajar matematika siswa yaitu jumlah aktivitas baik dan sangat baik adalah $71,43 \%$ dari banyak siswa dan sudah memenuhi syarat aktivitas belajar matematika meningkat yaitu jumlah aktivitas baik dan sangat baik adalah $\geq 70 \%$ dari banyak siswa.

\section{KESIMPULAN}

Penerapan metode penemuan terbimbing dapat meningkatkan aktivitas belajar siswa pada materi kubus dan balok. Hal ini dapat dilihat dari tingkat aktivitas siswa pada siklus I dan siklus II mengalami peningkatan. Pada siklus I diperoleh aktivitas siswa yang masuk kategori baik dan sangat baik adalah 14 siswa $(33,34 \%)$ dari 42 siswa dan Pada siklus II diperoleh bawah aktivitas siswa yang masuk kategori baik dan sangat baik meningkat menjadi 30 siswa $(71,43 \%)$. Penerapan metode penemuan terbimbing dapat meningkatkan hasil belajar siswa pada materi kubus dan balok. Hal ini dapat dilihat pada tes awal diperoleh bahwa dari 42 siswa, siswa yang penguasaannya sangat rendah ada 20 siswa $(47,62 \%), 11$ siswa $(26,19 \%)$ memiliki tingkat penguasaan rendah dan ada sebanyak 11 siswa $(26,19 \%)$ yang mencapai penguasaan sedang. Tidak ada siswa yang mencapai kategori tinggi dan sangat tinggi. Jumlah siswa yang tuntas sebanyak 11 siswa $(26,19 \%)$ dengan rata-rata kelas adalah 58,12. Pada siklus I siswa yang penguasaannya termasuk kategori tinggi ada 4 siswa $(9,52 \%)$, kategori sedang ada sebanyak 22 siswa $(52,38 \%)$, kategori rendah ada sebanyak 11 siswa $(26,19 \%)$, kategori sangat rendah ada sebanyak 5 siswa $(11,91 \%)$. Jumlah siswa yang tuntas sebanyak 26 siswa $(61,90 \%)$ dengan ratarata kelas adalah 68,17. Pada siklus II diperoleh ada 9 siswa $(21,49 \%)$ yang termasuk dalam kategori sangat tinggi, 16 siswa $(38,10 \%)$ yang termasuk dalam kategori tinggi, 12 siswa $(28,57 \%)$ yang termasuk dalam kategori sedang, 3 siswa $(7,14 \%)$ yang termasuk dalam kategori rendah, dan 2 siswa $(4,76 \%)$ yang termasuk dalam kategori sangat rendah. Jumlah siswa yang tuntas sebanyak 37 siswa $(88,10 \%)$ dengan rata-rata kelas adalah 79,35.

Marojahan Panjaitan, Gerham Gultom Upaya Meningkatkan Aktivitas dan Hasil Belajar Siswa dengan Penerapan Metode Penemuan Terbimbing pada Materi Kubus dan Balok di Kelas VIII SMP Swasta Brigjend Katamso Medan. Jurnal Inspiratif, Vol. 3, No. 3 Desember 2017. 


\section{DAFTAR PUSTAKA}

Abdurrahman, Mulyono., (2012), Pendidikan Bagi Anak Berkesulitan Belajar, Penerbit Rineka Cipta, Jakarta.

Arikunto, Suharsimi., (2011), Prosedur Penelitian, Penerbit Rineka Cipta, Jakarta.

Hamid, Abdul., (2009), Teori Belajar dan Pembelajaran, Penerbit Pasca Sarjana Unimed, Medan.

Kunandar., (2012), Langkah Mudah Penelitian Tindakan Kelas Sebagai Pengembangan Profesi Guru, Penerbit PT. Raja Grafindo Persada, Jakarta.

Kunandar., (2008), Guru Profesional Implementasi Tingkat Satuan Pendidikan (KTSP) dan Sukses Dalam Sertifikasi Guru, Penerbit PT. Raja Grafindo Persada, Jakarta.

Purwanto., (2011), Evaluasi Hasil Belajar, Penerbit Pustaka Pelajar, Yogyakarta.
Rohani, Ahmad., (2004), Pengelolaan Pengajaran, Penerbit Rineka Cipta, Jakarta.

Sardirman., (2011), Interaksi dan Motivasi Belajar Mengajar, Penerbit Raja Grafindo Persada, Jakarta.

Slameto., (2012), Belajar dan Faktor-faktor yang Mempengaruhinya, Penerbit Rineka Cipta, Jakarta.

Surya, E., Sabandar, J., Kusumah, Y.S., and Darhim. (2013). Improving of Junior High School Visual Thinking Representation Ability in Mathematical Problem Solving by CTL. IndoMS. J.M.E, Vol. 4 No. 1, pp. 113-126.

Surya Edy. 2013. Analisis Pemetaan dan Pengembangan Model Pembelajaran Matematika SMA di Kabupaten Tapteng dan Kota Sibolga Sumatera Utara. Jurnal Pendidikan Matematika PARADIKMA, Vol 6 Nomor 1, hal 75-88. 